\title{
ГОСТРА РЕСПІРАТОРНА ХВОРОБА, СПРИЧИНЕНА КОРОНАВІРУСОМ SARS-COV-2 У ЗБРОЙНИХ СИЛАХ УКРАЇНИ
}

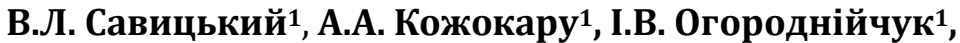 \\ Н.С. Івачевська ${ }^{2}$, Д.І. Доброштан ${ }^{3}$, В.В. Нарожнов ${ }^{1}$, В.М. Якимець ${ }^{4}$
}

\author{
1 Українська військово-медична академія, м. Київ, Україна \\ 227 регіональне санітарно-епідеміологічне управління, м. Одеса, Україна \\ ${ }^{3}$ Командування Медичних сил Збройних сил України м. Київ, Україна \\ ${ }^{4}$ ДНУ “Центр інноваційних медичних технологій НАН України" м. Київ, Україна
}

Мета. Здійснити порівняльний аналіз захворюваності на COVID-19 серед військовослужбовців Збройних Сил та цивільним населенням України на території відповідальності регіональних санітарноепідеміологічних управлінь КМС ЗС Украӥни для подальшого вивчення особливостей перебігу хвороби та наслідків інфікування вірусом SARS-CoV-2.

Матеріали та методи. Аналізували опубліковані у ЗМІ характеристики епідеміологічного стану наслідків інфікування вірусом SARS-CoV-2 у краӥнах з найбільшою на час дослідження чисельністю інфікованих осіб, суміжних до України державах: захворюваність на COVID-19 серед військовослужбовців та працівників ЗС України вивчали з використанням електронної бази щоденних донесень щодо стану поширення гострої респіраторної хвороби COVID-19, спричиненої коронавірусом SARS-CoV-2 на території Украӥни та хід виконання заходів по запобіганню ї̈ поширення у ЗС України надану СЕУ КМС ЗС Украӥни. Методи дослідження - бібліосемантичний, епідеміологічнй, соціологічний та концептуального моделювання.

Результати. У статті розглянуто проблему захворюваності на гостру респіраторну хворобу, спричинену коронавірусом SARS-CoV-2 (далі - COVID-19) серед населення України та військовослужбовців Збройних сил. У дослідженнях відслідковується різниця у співвідношенні кількісних показників серед військовослужбовців, які одужали - 2247 осіб (79,5\%) та цивільного населення -92 360(44,0\%) України. Зазначено, що з точки зору безпеки держави COVID-19 - це є приклад біологічної атаки на суспільство країни і готовність держави до захисту населення.

Висновки. За результатами проведеного аналізу спостерігається різниця у співвідношенні кількісних показників серед одужавших військовослужбовців - 2247 осіб (79,5\%) та цивільного населення 92360 (44,0\%) України при цьому левову частку виявлених позитивних результатів ПлР-тестування на SARS-CoV-2 спостерігається серед військовослужбовців частин, які дислоковані на території відповідальності в/ч А 4520 (36.1\%) та в/ч А 0972 (35.3\%), що корелює з показниками захворюваності цивільного населення цих регіонів. 3 точки зору безпеки держави, COVID-19 - це є приклад біологічної атаки на суспільство країни і готовність держави до захисту населення. Висока здатність коронавірусів до мутації та поширення у популяції людей, смертність від ускладнень, у тому числі від пневмонії, а з іншого боку - високий відсоток безсимптомного та легкого перебігу хвороби обумовлює виникнення суперечок та напруження у суспільстві, створює величезний тиск на економіку держави. Боротьба з новими вірусними захворюваннями вимагає посиленого розвитку сучасних методів лабораторної діагностики (ПЛР, ІФА), підготовки фахівців вірусологів, впровадження швидких діагностичних тест-систем в лікувальні заклади ЗС України.

Ключові слова: коронавірус, захворюваність, COVID-19, SARS-CoV-2, військовослужбовці.

Вступ. Із захворюванням на COVID-19 Україна, як і весь світ у масштабах пандемії з такою кількістю інфікованих за короткий період зустрічається вперше. Так, за останні два тисячоліття людство пережило не одну пандемію. Такі пандемії, як “Чорна смерть" (чума) у XIV сторіччі, холера у XIX сторіччі та “іспанка" у 1918-1920 роках призводили до великих демографічних втрат і трагедій. Дане явище, чи не вперше змусило фахівців провідних країн застосувати на практиці новий метод карантину, який не обмежувався певною установою, або територією, і навіть не регіоном, а впроваджувався на території цілої держави і всього світу. Він характеризується впровадженням заходів на рівні міждержавних відносин: закриття кордонів, повернення трудових мігрантів та інших категорій осіб до своїх країн, скасування транспортних сполучень з іншими державами у т.ч. авіаперельотів; впровадженням карантинних заходів у середині країни: самоізоляція вдома, яка включає широкий спектр змін взаємовідносин як у сімейному колі, так і на рівні суспільства в цілому. Самоізоляція - явище, яке змусило органи 
самоврядування внести тимчасові корективи в трудові, побутові та інші взаємовідносини між організаціями, членами суспільства, явище, яке потребує ще подальшого вивчення.

Наразі вже відомі три нових коронавіруси, які були виділені від людини у XXI столітті: коронавірус SARS-CoV тяжкого гострого респіраторного синдрому; коронавірус MERS $\mathrm{CoV}$ Близькосхідного респіраторного синдрому та новий штам - коронавірус SARSCoV-2, який викликає висококонтагіозне інфекційне гостре респіраторне захворювання COVID-19. Спалах даного захворювання швидко поширився в глобальному масштабі. У людей, інфікованих цим вірусом, може не бути ознак хвороби, у інших можуть бути симптоми, включаючи лихоманку, кашель, задишку і біль в горлі. У деяких людей інфекція характеризується ускладненим перебігом i може викликати затруднене дихання, що $\epsilon$ наслідком розвитку запалення легень та призводить до госпіталізації, переведення у відділення інтенсивної терапї̈ або до смерті. В даний час немає ні вакцини, ні специфічного лікування.

Мета дослідження - порівняльний аналіз захворюваності на COVID-19 серед військовослужбовців Збройних Сил та цивільним населенням України на території відповідальності регіональних санітарноепідеміологічних управлінь КМС ЗС України для подальшого вивчення особливостей перебігу хвороби та наслідків інфікування вірусом SARS-CoV-2.

Матеріали та методи дослідження. Вивчення COVID-19 в Україні та у Збройних силах розпочинали з аналізу опублікованих у 3MI характеристиках епідеміологічного стану з даної інфекції у країнах з найбільшою на час дослідження чисельністю інфікованих осіб, суміжних до України державах: Росія, Туреччина, Польща, Румунія, Білорусь, Молдова, Угорщина, Словаччина, Болгарія, Грузія та країнах, в яких виконують завдання національні контингенти та персонал 3С України (миротворчі контингенти): Сербія, Кіпр, Афганістан, Косово, ДР Конго, Малі, Південний Судан. Щодо захворюваності на COVID-19 серед військовослужбовців та працівників ЗС України використовували електронну базу щоденних донесень щодо стану поширення гострої респіраторної хвороби COVID-19, спричиненої корона вірусом SARS-CoV-2 на території України та хід виконання заходів по запобіганню пї поширення у ЗС України надану СЕУ КМС ЗС
України.

Об'єкт дослідження - військовослужбовці та працівники Збройних Сил, а також цивільне населення України. Предмет дослідження епідеміологічнй процес пов'язаний 3 інфікуванням та поширенням SARS-CoV-2 серед військовослужбовців та населення України. Методи дослідження - бібліосемантичний, епідеміологічнй, соціологічний та концептуального моделювання.

Результати дослідження та їх обговорення. До країн 3 найбільшою на час дослідження чисельністю інфікованих осіб відносились: США, Іспанія, Італія, Франція, Німеччина, Великобританія, КНР, Іран [1]. 3 восьми перерахованих країн шість знаходяться на території європейського континенту, що може пояснюватись значною активністю населення даних країн щодо бізнесу, освіти, відпочинку тощо. Саме ці країни найбільш насичені емігрантами зі східних та африканських країн.

3 оголошенням карантину в Україні фахівцями Командування Медичних сил Збройних Сил України було розроблено план та удосконалено наявну схему перспективного перепрофілювання закладів охорони здоров'я в системі Міністерства оборони України у разі масового надходження військовослужбовців хворих на гостру респіраторну хворобу, спричинену коронавірусом SARS-CoV-2. У всіх Військово-медичних клінічних центрах регіонів та військових госпіталях зон відповідальності, за участі фахівців Служби превентивної медицини Міністерства оборони України, були проведені практичні заняття щодо особливостей функціювання лікувального закладу в умовах суворого протиепідемічного режиму, при виявлені хворого з підозрою на COVID-19. Створено запас медико-санітарного, господарчого майна, дезінфекційних, необхідних лікарських засобів та засобів індивідуального захисту медичного персоналу закладів охорони здоров'я Збройних Сил України та продовжується його накопичення [2].

Коронавіруси (порядок Nidovirales, сімейство Coronaviridae, під сімейство Orthocoronaviridae) вперше було виділено від курей у 1937 році, а коронавірус людини вперше одержали 3 культури війчастого епітелію трахеї людського зародка у 1965 році [3, 4]. За офіційними даними КНР, захворювання на COVID-19 було виявлено 17 листопада 2019 року у 55-річної особи з міста Ухань, провінція Хубей [5]. Перші випадки 
захворювання пов'язували 3 ринком морепродуктів в Ухані, однак за даними дослідження, опублікованого в журналі Lancet, деякі люди з числа перших інфікованих SARSCoV-2 не мали безпосереднього контакту з цим ринком [6, 7]. 31 грудня 2019 року В003 дає перше офіційне повідомлення про хворих в Китаї, 2 березня 2020 року зареєстровано перший випадок в Україні, цей день став початком епідемії в Україні, 11 березня 2020 року В003 офіційно оголосила пандемію коронавірусу у світі [8]. Востаннє до того В003 оголошувала пандемію у 2009 році під час спалаху “свинячого грипу" А/H1N1[9].

12 березня 2020 року - день оголошеного карантину в Україні. Введення подібних заходів на поширення хвороби детально досліджено у масштабній роботі, де показано, що введення карантину в 11 європейських країнах дозволило уникнути від 21 до 120 тис. смертей [10].

В Україні за даними M03 за період «суворого» та адаптивного карантину (12.03.2020 - 30.09.2020) лабораторно підтверджено 208959 випадків, із них 4129 (2.0\%) летальних, 92360 (44.0\%) одужало.

у Збройних силах перший випадок захворювання на гостру респіраторну хворобу, спричинену коронавірусом SARS-CoV-2 був зареєстрований 1 квітня 2020 року (працівник 3СУ), натомість в Україні в цілому було підтверджено 804 випадки. Перший летальний випадок був зареєстрований 6 квітня 2020 року (працівник ЗСУ), всього в Україні на той час вже було зафіксовано 45 летальних випадків.

За даними Санітарно-епідеміологічного управління Командування медичних Сил за період від першого підтвердженого випадку (01.04.2020-30.09.2020) лабораторно підтверджено у Збройних силах 2825 випадків захворювання. Діагноз COVID-19 виставлявся за результатами позитивного ПЛРтестування. У середньому за добу під час “суворого” карантину фіксувалося 5 випадків захворювання та 30 під час адаптивного карантину. За результатами проведеного лікування одужало - 2 247осіб (79.5\%); летальних випадків - 10 (0.35\%), з яких 2 особи - офіцери, 8 осіб - працівники 3С України. Співвідношення цих показників відображено на рис. 1.

3 числа лабораторно підтверджених випадків COVID-19 найбільшу питому вагу складали офіцери - 1162 (41.1\%) особи та військовослужбовці за контрактом - 817
(28.9\%) осіб. Далі у порядку зменшення держслужбовці та працівники ЗС України - 573 (20.3\%) особи, військовослужбовці строкової служби - 202 (7.2\%) особи, курсанти - 71 (2.5\%) особа. Співвідношення випадків інфікування на COVID-19 всіх категорій військовослужбовців та працівників Збройних сил за період карантину до 30.09.2020 включно відображено на рис. 2.
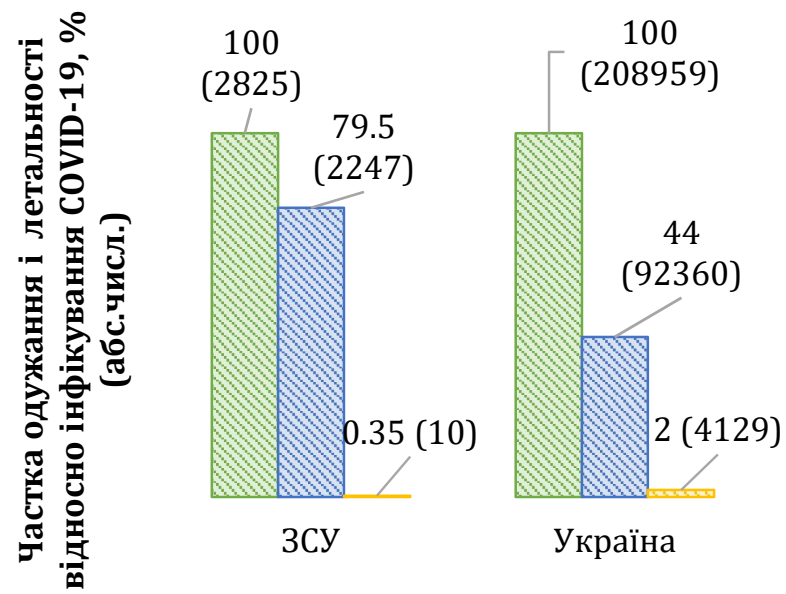

囚 Лабораторно підтверджені

จ Одужали

Летальні випадки

\begin{tabular}{cccr}
\multicolumn{1}{c}{ Рисунок } & 1. & Структура & показників \\
одужання & та & летальності & відносно
\end{tabular} лабораторно підтверджених випадків COVID19 у збройних силах та в Україні станом на 30.09.2020 p.

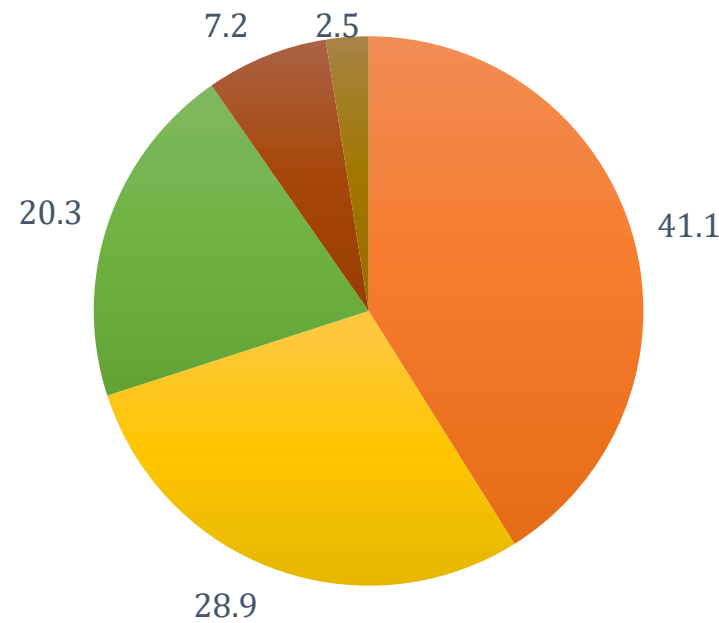

Офіцери

В/с за контрактом

- Працівники ЗСУ

- В/с строкової служби

- Курсанти

Рисунок 2. Структура захворюваності на COVID-19 серед усіх категорій військовослужбовців та працівників Збройних Сил України станом на 30.09.2020 р., \%. 
Кількість випадків COVID-19 за результатами позитивного ПЛР-тестування серед усіх категорій військовослужбовців та працівників Збройних Сил України на території відповідальності Регіональних санітарно-епідеміологічних управлінь відображено на рис. 3 .

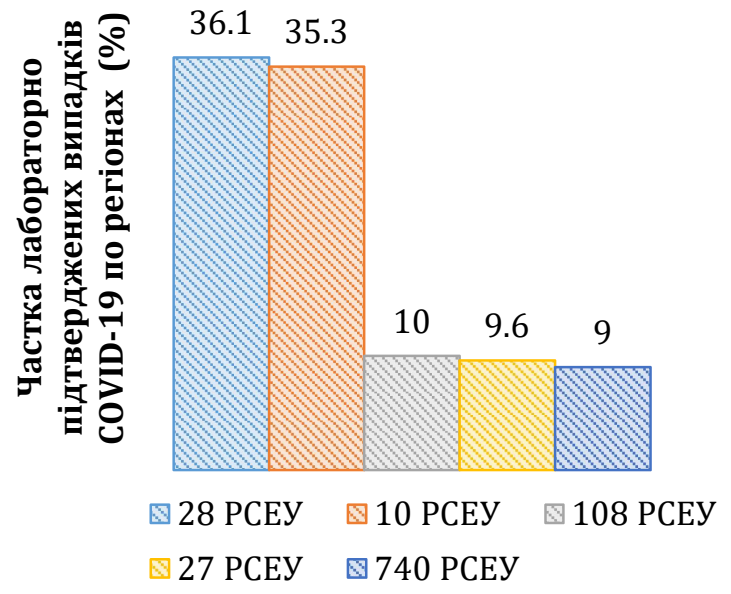

Рисунок 3. Структура захворюваності на COVID-19 по регіонах відповідальності Регіональних санітарно-епідеміологічних управлінь Служби превентивної медицини станом на 30.09.2020 p.

Таким чином, за результатами проведеного аналізу спостерігається різниця у співвідношенні кількісних показників серед

\section{Висновки}

1. За результатами проведеного аналізу спостерігається різниця у співвідношенні кількісних показників серед одужавших військовослужбовців - 2247 осіб $(79,5 \%)$ та цивільного населення - 92360 (44,0\%) України, при цьому левову частку виявлених позитивних результатів ПЛР-тестування на SARS-CoV-2 спостерігається серед військовослужбовців частин, які дислоковані на території відповідальності в/ч А 4520 (36.1\%) та в/ч А 0972 (35.3\%), що корелює 3 показниками захворюваності цивільного населення цих регіонів.

2. 3 точки зору безпеки держави, COVID19 - це $\epsilon$ приклад біологічної атаки на суспільство країни і готовність держави до

\section{Література \\ References}

1. Rud, I. Pandemic: the latest news (2020). Ukraine: events, facts, comments. 8. 49-53. - Retrived on 03.10.2020. - Access mode: http://nbuviap.gov.ua/ images/ukraine/2020/ukr8.pdf.

2. Measures of the Armed Forces of Ukraine to prevent одужавших військовослужбовців - 2247 осіб $(79,5 \%)$ та цивільного населення - 92360 (44,0\%) України. Найбільша кількість виявлених позитивних результатів ПЛРтестування на SARS-CoV-2 спостерігається серед військовослужбовців частин, які дислоковані на території відповідальності в/ч А 4520 (36.1\%) та в/ч А 0972 (35.3\%), що співставно 3 показниками захворюваності цивільного населення цих регіонів.

COVID-19, з точки зору безпеки держави $є$ прикладом біологічної атаки на суспільство країни i готовність держави до захисту населення. Навіть розвинуті держави Європи не були готові до боротьби із збудником SARSCoV-2 (відсутні протоколи лікування, медичні препарати), відсутні біопрепарати (вакцини).

Висока здатність коронавірусів до мутації та поширення у популяції людей, смертність від ускладнень, у тому числі від пневмонії, а 3 іншого боку - високий відсоток безсимптомного та легкого перебігу хвороби обумовлює виникнення суперечок та напруження у суспільстві, створює величезний тиск на економіку держави. Тому боротьба 3 вірусами вимагає посиленого розвитку сучасних методів лабораторної діагностики (ПЛР, ІФА), підготовки фахівців вірусологів, впровадження швидких діагностичних тестсистем в лікувальні заклади ЗС України.

захисту населення. Висока здатність коронавірусів до мутації та поширення у популяції людей, смертність від ускладнень, у тому числі від пневмонії, а 3 іншого боку високий відсоток безсимптомного та легкого перебігу хвороби обумовлює виникнення суперечок та напруження у суспільстві, створює величезний тиск на економіку держави.

3. Боротьба 3 новими вірусними захворюваннями вимагає посиленого розвитку сучасних методів лабораторної діагностики (ПЛР, ІФА), підготовки фахівців вірусологів, впровадження швидких діагностичних тест-систем в лікувальні заклади ЗС України.

the introduction and spread in Ukraine of acute respiratory disease COVID-19 caused by coronavirus SARS-CoV-2. Ministry of Defence Ukraine. - Retrived on 03.10.2020. - Access mode: https://www.mil.gov.ua Lnews/2020/03/24/zahodi-zsu-shhodo-zapobigannya- 
zanesennyu-i-poshirennyu-v-ukraini-gostroi-respira tornoi-hvorobi-covid-19-sprichinenoi-koronavirusomsars-cov-2/?fbclid=IwAR0mnebP0RhxYWNLJDjY rCE6UqC5DCi2AVdgFwcBqkoI2arWoqis46Yk4fY.

3. Beaudette, F.R., Hudson, C.B. (1937). Cultivation of the virus of infectious bronchitis. J. Am. Vet. Med. Assoc. 90: 51-58.

4. Tyrrell, D.A., Bynoe, M.l. (1965). Cultivation of a novel type of common-cold virus in organcultures. $\mathrm{Br}$. Med. J. 1 (5448): 1467-1470. https://doi.org $\angle 10.1136 / \mathrm{bmj} .1 .5448 .1467$.

5. Davidson, H. First Covid-19 casehappenedin November, China government records - Retrived on 03.10.2020. - Access mode: https://www. theguardian.com/world/2020/mar/13/first-covid19-case-happened-in-november-china-governmentrecordsshow-report.

6. Huang, C., Wang, Y., Li, X. Et al. (2020). Clinical features of patients infected with 2019 novel coronavirus in Wuhan. China. Lancet. 395(10223). 497-506. https://doi.org/10.1016/S0140-6736(20)30183-5.

7. Wu,F., Zhao,S., Yu,B., Chen,Y.M., Wang,W., Song,Z.G.,
Hu,Y.,Tao,Z.W., Tian,J.H., Pei,Y.Y., Yuan,M.L., Zhang,Y.L., Dai,F.H., Liu,Y., Wang,Q.M., Zheng,J.J., Xu,L., Holmes,E.C. and Zhang,Y.Z. (2020). A new coronavirus associated with human respiratory disease in China. Nature. 579 (7798), 265-269. https://doi.org/10.1038/s41586-020-2008-3.

8. WHO Director-General's opening remarks at the media briefing on COVID-19-11 March 2020. World Health Organization. 11 March 2020. - Retrived on 03.10.2020. - Access mode: https://www.who.int/ $\mathrm{dg} /$ speeches/detail/who-director-general-s-openingremarks-at-the-media-briefing-on-covid-19---11-march$\underline{2020 .}$

9. Trifonov, V., Khiabanian, H., Rabadan, R. (9 July 2009). Geographic Dependence, Surveillance, and Originsofthe 2009 Influenza A (H1N1) Virus. New England Journal of Medicine $361 \quad$ (2): 115-19. https://doi.org/10.1056/NEJMp0904572.

10. Flaxman, S., Mishra, S., Gandy, A. et al. (2020). Estimating the effects of non-pharmaceutical interventions on COVID-19 in Europe. Nature. 584, 257261 https://doi.org/10.1038/s41586-020-2405-7.

\title{
ОСТРОЕ РЕСПИРАТОРНОЕ ЗАБОЛЕВАНИЕ, ВЫЗВАННОЕ КОРОНАВИРУСОМ SARS-COV-2 В ВООРУЖЕННЫХ СИЛАХ УКРАИНЫ
}

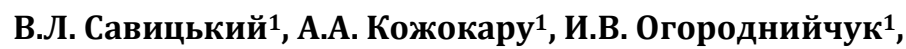 \\ Н.С. Ивачевская ${ }^{2}$, Д.И. Доброштан ${ }^{3}$, В.В. Нарожнов ${ }^{1}$, В.М. Якимец
}

\author{
1 Украинсская военно-медицинская академия, г. Киев, Украина. \\ 227 региональное санитарно-эпидемиологическое управление, Г. Одесса, Украина \\ ${ }^{3}$ Командование Медицинских сил Вооруженных сил Украины г. Киев, Украина \\ ${ }^{4}$ ГНУ «Центр инновационных медицинских технологий НАН Украины» г. Киев, Украина.
}

Цель. Осуществить сравнительный анализ заболеваемости COVID-19 среди военнослужащих Вооруженных Сил и гражданским населением Украины на территории ответственности региональных санитарно-эпидемиологических управлений КМС ВС Украины для дальнейшего изучения особенностей течения болезни и последствий инфицирования вирусом SARS-CoV-2.

Материалы и методы. Анализировали опубликованные в СМИ характеристики эпидемиологического состояния последствий инфицирования вирусом SARS-CoV-2 в странах прилегающих к Украине с наибольшей на время исследования численностью инфицированных: заболеваемость COVID-19 среди военнослужащих и работников ВС Украины изучали с использованием электронной базы ежедневных донесений по состоянию распространения острой респираторной болезни COVID-19, вызванной коронавирусом SARS-CoV-2 на территории Украины и ход выполнения мероприятий по предотвращению ее распространения в ВС Украины предоставленную СЭУ КМС ВС Украины. Методы исследования библиосемантичний, эпидемиологические, социологический и концептуального моделирования.

Результаты. В статье рассмотрена проблема заболеваемости острой респираторной болезни, вызванной коронавируса SARS-CoV-2 (далее - COVID-19) среди населения Украины и военнослужащих Вооруженных сил. В исследованиях прослеживается разница в соотношении количественных показателей среди военнослужащих, выздоровели - 2 247осиб (79,5\%) и гражданского населения -92360 (44,0\%) Украины. Отмечено, что с точки зрения безопасности государства COVID-19 - это пример биологической атаки на общество страны и готовность государства к защите населения.

Выводы. По результатам проведенного анализа наблюдается разница в соотношении количественных показателей среди выздоровевших военнослужащих - 2247 человек (79,5\%) и гражданского населения - 92360 (44,0\%) Украины при этом львиную долю выявленных положительных результатов ПЦР-тестирования на SARS-CoV -2 наблюдается среди военнослужащих в частях, дислоцированных на территории ответственности в / ч A 4520 (36.1\%) и в / ч А 0972 (35.3\%), что коррелирует с показателями заболеваемости гражданского населения этих регионов. С точки зрения безопасности государства, COVID19 - это пример биологической атаки на общество страны и готовность государства к защите населения. Высокая способность коронавирусов к мутации и распространению в популяции людей, смертность от осложнений, в том числе от пневмонии, а с другой - высокий процент бессимптомного и легкого течения 
болезни обусловливает возникновение споров и напряжение в обществе, создает огромное давление на экономику государства. Борьба с новыми вирусными заболеваниями требует усиленного развития современных методов лабораторной диагностики (ПЦР, ИФА), подготовки специалистов вирусологов, внедрение быстрых диагностических тест-систем в лечебные учреждения ВС Украины.

Ключевые слова: коронавирус, заболеваемость, COVID-19, SARS-CoV-2, военнослужащие.

\title{
ACUTE RESPIRATORY DISEASE CAUSED BY CORONAVIRUS SARS-CoV-2 IN THE ARMED FORCES OF UKRAINE
}

\author{
V.L. Savytskyi ${ }^{1}$, A.A. Kozhokaru' ${ }^{1}$ I.V. Ohorodniychuk ${ }^{1}$, \\ N.S. Ivachevska'2, D.I. Dobroshtan ${ }^{3}$, V.V. Narozhnov ${ }^{1}$, V.M. Yakymets ${ }^{4}$ \\ ${ }^{1}$ Ukrainian Military Medical Academy, Kyiv, Ukraine \\ 227 Regional Sanitary and Epidemiological Department, Odessa, Ukraine \\ 3 Medical Forces Command of the Armed Forces of Ukraine, Kyiv, Ukraine \\ ${ }^{4}$ SRI «Center for Innovative Medical Technologies of the NAS of Ukraine», Kyiv, Ukraine
}

The purpose. Carry out a comparative analysis of the incidence of COVID-19 among servicemen of the Armed Forces and the civilian population of Ukraine in the area of responsibility of the regional sanitaryepidemiological departments of the MFC of the Armed Forces of Ukraine to further study the disease and the consequences of SARS-CoV-2 virus infection.

Materials and methods. The characteristics of the epidemiological status of the consequences of SARS-CoV2 virus infection in the countries with the largest number of infected persons adjacent to Ukraine at the time of the study were analyzed: the incidence of COVID-19 among servicemen and employees of the Armed Forces of Ukraine was studied the state of spread of acute respiratory disease COVID-19 caused by coronavirus SARS-CoV-2 on the territory of Ukraine and the course of implementation of measures to prevent its spread in the Armed Forces of Ukraine provided by the MFC of the Armed Forces of Ukraine. Research methods - bibliosemantic, epidemiological, sociological and conceptual modeling.

Results. The article considers the problem of the incidence of acute respiratory disease caused by the coronavirus SARS-COV-2 (hereinafter - COVID-19) among the population of Ukraine and servicemen of the Armed Forces. The research shows a difference in the ratio of quantitative indicators among the servicemen who recovered $-2,247$ people (79.5\%) and the civilian population - 92,360 (44.0\%) of Ukraine. It is noted that from the point of view of state security, COVID-19 is an example of a biological attack on the country's society and the state's readiness to protect the population.

Conclusions. According to the results of the analysis, there is a difference in the ratio of quantitative indicators among the recovered servicemen - 2,247 people (79.5\%) and the civilian population-92,360 (44.0\%) of Ukraine, with the lion's share of positive PCR test results for SARS-CoV -2 is observed among the servicemen of the units stationed on the territory of the unit A 4520 (36.1\%) and unit A 0972 (35.3\%), which correlates with the morbidity rates of the civilian population of these regions. From the point of view of state security, COVID-19 is an example of a biological attack on the country's society and the state's readiness to protect the population. The high ability of coronaviruses to mutate and spread in human populations, mortality from complications, including pneumonia, and on the other hand - a high percentage of asymptomatic and mild disease causes controversy and tension in society, creates enormous pressure on the economy. The fight against new viral diseases requires intensive development of modern methods of laboratory diagnosis (PCR, ELISA), training of virologists, the introduction of rapid diagnostic test systems in medical institutions of the Armed Forces of Ukraine.

Key words: coronavirus, morbidity, COVID-19, SARS-CoV-2, servicemen

Конфлікт інтересів: відсутній.

Conflicts of interest: authors have no conflict of interest to daclare.

Відомості про авторів:

Савицький В.Л. А,С,Е,F - полковник медичної служби, доктор медичних наук, професор, начальник Української військово-медичної академії, м. Київ.

Кожокару A.A. B,C,D,E - полковник медичної служби, доктор медичних наук, професор, начальник кафедри військово-профілактичної медицини Української військово-медичної академії, м. Київ.

Огороднійчук I.B. B,C,D,E - підполковник медичної служби, доктор медичних наук, доцент, професор кафедри військово-профілактичної медицини Української військово-медичної академії, м. Київ.

Івачевська Н.С. В,C,D - лейтенант медичної служби, лікар санітарно-гігієнічного відділення санітарно-гігієнічного відділу27 регіонального санітарно-епідеміологічногоуправління, м. Одеса.

Доброштан Д.I. C,D,E - капітан медичної служби, офіцер епідеміологічного відділу санітарноепідеміологічного управління Командування медичних сил Збройних Сил України, м. Київ. 
Нарожнов B.B. D,E - доктор медичних наук, професор, старший науковий співробітник НДВ (створення та модернізації медичної техніки) НДІ ПВМ Української військово-медичної академії, м. Київ.

Якимець В.М. D,E - доктор медичних наук, професор, заступник директора ДНУ “Центр інноваційних медичних технологій НАН України", м. Київ.

$A$ - концепція та дизайн дослідження; $B$ - збір даних; $C$ - аналіз та інтерпретація даних;

$D$ - написання статmi; $E$ - редагування статті; F- остаточне затвердження статті.

\section{Сведения об авторах:}

Савицкий В.Л. - полковник медицинской службы, доктор медицинских наук, профессор, начальник Украинской военно-медицинской академии, г. Киев.

Кожокару А.А. -полковник медицинской службы, доктор медицинских наук, профессор, начальник кафедры военно-профилактической медицины Украинской военно-медицинской академии, г. Киев.

Огороднийчук И.В. -подполковник медицинской службы, доктор медицинских наук, доцент, профессор кафедры военно-профилактической медицины Украинской военно-медицинской академии, г. Киев.

Ивачевская Н.С. -лейтенант медицинской службы, врач санитарно-гигиенического отделения санитарно-гигиенического отдела 27 регионального санитарно-епидемиологичногоуправлиння, г. Одесса.

Доброштан Д.I. - капитан медицинской службы, офицер эпидемиологического отдела санитарноэпидемиологического управления Командования медицинских сил Вооруженных Сил Украины, г. Киев.

Нарожнов В.В. -доктор медицинских наук, профессор, старший научный сотрудник НИО (создания и модернизации медицинской техники) НИИ ПВМ Украинской военно-медицинской академии, г. Киев.

Якимец В.Н. -доктор медицинских наук, профессор, заместитель директора ГНУ «Центр инновационных медицинских технологий НАН Украины», г. Киев.

\section{Information about authors:}

Savytskyi V.L. A,B,C,D,E - Col. MS, Doctor of Medical Sciences, Professor, Chief of Ukrainian Military Medical Academy, Email: savvalleon@ukr.net, https://orcid.org/0000-0001-8027-0163, Kyiv.

Kozhokaru A.A. ${ }^{B, C, D, E}-$ Col. MS, Doctor of Medical Sciences, Professor, Chief of the Department of Military Preventive Medicine of Ukrainian Military Medical Academy, Email: Addrik@bigmir.net, https://orcid.org/00000002-8233-421X, Kyiv.

Ohorodniychuk I.V. B,C,D,E - LtC. MS, Doctor of Medical Sciences, Associate professor, Professor of the Department of Military Preventive Medicine of Ukrainian Military Medical Academy, Email:iro4ka.ogo@ukr.net, https://orcid.org/0000-0003-1063-1829, Kyiv.

Ivachevska N.S. ${ }^{\mathrm{B}, \mathrm{C}, \mathrm{D}}$ - Lt. MS, doctor of the sanitary and hygienic section of the sanitary and hygienic department of the 27 th Regional sanitary and epidemiological administration, Odessa.

Dobroshtan D.I. C,D,E - Cpt. MS, Officer of the Epidemiological Department of the Sanitary and Epidemiological Administration of the Medical Forces Command of the Armed Forces of Ukraine, Kyiv.

Narozhnov V.V. D,E - Doctor of Medical Sciences, Professor, Senior Researcher of the Research Institute of Military Medicine of the Ukrainian Military Medical Academy, https://orcid.org/0000-0003-3717-8403, Kyiv.

Yakymets V.M. D,E - Doctor of Medical Sciences, Professor, Deputy Director of the Center for Innovative Medical Technologies of the National Academy of Sciences of Ukraine, https://orcid.org/0000-0002-0170-024X, Kyiv.

$A$ - research concept and design; $B$ - collection and/or assembly of data; $C$ - data analysis and interpretation; $D$ writing the article; $E$ - critical revision of the article; $F$ - final approval of the article.

Адреса для листування: вул. Московська, 45/1, буд. 33, м. Київ 01015 